\title{
ASSESSING LOSS DEPENDENT UPON HyPothetical PASt Events
}

\section{SIRKO HARDER*}

The assessment of loss allegedly caused by a civil wrong depends upon what would have happened but for the wrong. Where this cannot be resolved with certainty, the plaintiff's loss must be assessed either on the balance of probabilities according to the more likely hypothesis (all or nothing), or by reference to the degree of probability that an event would have occurred but for the defendant's wrong (partial recovery). Australian courts have not subjected all uncertain events to a single approach. This article explores how the courts have approached the various categories of hypothetical past events, and how the plaintiff's loss will be assessed where multiple events of different types are inextricably interwoven.

\section{INTRODUCTION}

The assessment of loss allegedly caused by a civil wrong requires the determination of whether particular events have occurred, or are likely to occur in the future, or would have occurred but for the wrong. ${ }^{1}$ For example, the assessment of loss of earning capacity caused by personal injury requires the court to determine (among other things) what jobs (if any) the plaintiff is likely to occupy in the future and what jobs she would have occupied but for the injury. To determine whether an event that allegedly occurred (for example a car driver exceeding the speed limit) did in fact occur may already be difficult. It is even more difficult to determine whether a particular event is likely to occur in the future or would have occurred had things been different. A court is rarely in a position to be certain about those matters.

\footnotetext{
* Reader, Sussex Law School. The author is grateful for helpful comments by an anonymous reviewer.

${ }^{1}$ Factual causation is usually determined by applying the 'but for' test. This article does not consider whether the use of another test makes a difference to the issues explored here. For those other tests, see Katy Barnett and Sirko Harder, Remedies in Australian Private Law (Cambridge University Press, 2014) 62, 65-9.
} 
Even where uncertainty remains, a decision on the plaintiff's claim must be made. In order to make this decision, a legal system has the choice between two basic approaches. ${ }^{2}$ First, the plaintiff's loss may be assessed by reference to the probability of the event occurring. Under that approach, the court determines the degree of probability that an event favouring the plaintiff has occurred, will occur, or would have occurred but for the act of the defendant, and then multiplies the percentage figure by the amount of loss that the event's occurrence would have prevented. It is a sliding scale. Alternatively, uncertainty as to the occurrence of an event may be resolved on the balance of probabilities. Under that approach, it is asked whether the event's occurrence or non-occurrence is more likely, and the more likely hypothesis forms the basis of assessing the plaintiff's loss. It is all or nothing. If, under that approach, it is more likely than not that the defendant's wrong has caused no loss to the plaintiff, substantial damages cannot be awarded (though nominal damages can be awarded if the wrong is actionable per se). Thus, the choice between the two basic approaches of resolving uncertainty may determine not only the extent but also the existence of liability.

To illustrate the two approaches, suppose that the plaintiff asserts that, but for the defendant's wrong, the plaintiff would have received $\$ 1000$ from a particular source. It cannot be determined with certainty whether or not this would in fact have happened. If the plaintiff's loss is determined by reference to the degree of probability, $\$ 1000$ will be multiplied by the degree of probability of the plaintiff receiving $\$ 1000$ but for the defendant's wrong. If that degree is, say, 25 per cent, the plaintiff's loss will be $\$ 250$. If the degree is, say, 75 per cent, the plaintiff's loss will be $\$ 750$. By contrast, if the uncertainty in the example is resolved on the balance of probabilities, it will be asked whether the hypothetical receipt, or non-receipt, of the $\$ 1000$ is more likely. If the receipt is more likely, the plaintiff's loss will be $\$ 1000$. If the non-receipt is more likely, the plaintiff's loss will be nil, and substantial damages cannot be awarded.

Australian courts have not subjected all uncertain events to a single approach. Indeed, they have created rather complex rules, and it may be necessary to apply one approach to some events and the other approach to other events in the same set of circumstances. This article explores the distinction made between different categories of hypothetical past event, which is an event that would allegedly have occurred before trial but for the defendant's wrong. ${ }^{3}$ In

\footnotetext{
${ }^{2}$ See Malec v J C Hutton Pty Ltd (1990) 169 CLR 638, 643-4.

${ }^{3}$ The phrases 'hypothetical past event', 'hypothetical past fact' and 'hypothetical past situation' have been used in many cases; eg Daniels v Anderson (1995) 37 NSWLR 438, 527; Fatimi Pty Ltd v Bryant [2004] NSWCA 140 (6 May 2004) [38]; Seltsam Pty Ltd v Ghaleb [2005]
} 
order to place the topic of this article in the wider picture, it is necessary to provide a brief overview of the rules created by the Australian courts.

The basic framework at common law, which has also been applied under the civil liability statutes, ${ }^{4}$ is contained in the following statement made by Deane, Gaudron and McHugh JJ in the High Court of Australia in Malec $v$ J C Hutton Pty Ltd:

When liability has been established and a common law court has to assess damages, its approach to events that allegedly would have occurred, but cannot now occur, or that allegedly might occur, is different from its approach to events which allegedly have occurred. A common law court determines on the balance of probabilities whether an event has occurred ... But in the case of an event which it is alleged would or would not have occurred, or might or might not yet occur, the approach of the court is different ... If the law is to take account of future or hypothetical events in assessing damages, it can only do so in terms of the degree of probability of those events occurring ... Thus, the court assesses the degree of probability that an event would have occurred, or might occur, and adjusts its award of damages to reflect the degree of probability. ${ }^{5}$

The High Court proceeded on the basis that uncertainty as to the occurrence of an event is generally resolved on the balance of probabilities, but the Court endorsed an assessment by reference to the degree of probability in relation to hypothetical past events (among others). ${ }^{6}$ This endorsement was made in the

NSWCA 208, (2005) 3 DDCR 1 [103]; Ridolfi v Hammond [2012] NSWCA 3 (23 February 2012) [87], [141]; Sneddon v New South Wales [2012] NSWCA 351 (1 November 2012) [103]; Molinara v Perre Bros Lock 4 Pty Ltd [2014] SASCFC 115 (30 October 2014) [40][48], [78]-[82]. See also Sellars v Adelaide Petroleum NL (1994) 179 CLR 332, 350-5 (Mason CJ, Dawson, Toohey and Gaudron JJ) ('past hypothetical fact situations').

${ }^{4}$ See, eg, Ridolfi v Hammond [2012] NSWCA 3 (6 February 2012) [84]-[88]; Donnellan $v$ Woodland [2012] NSWCA 433 (18 December 2012) [235]-[239]. The civil liability statutes of all Australian states and the Australian Capital Territory provide that the plaintiff must prove, on the balance of probabilities, any fact relevant to causation: Civil Liability Act 2002 (NSW) s 5E; Civil Liability Act 2003 (Qld) s 12; Civil Liability Act 1936 (SA) s 35; Civil Liability Act 2002 (Tas) s 14; Wrongs Act 1958 (Vic) s 52; Civil Liability Act 2002 (WA) s 5D; Civil Law (Wrongs) Act 2002 (ACT) s 46. An assessment of loss by reference to the degree of probability despite such a provision has been defended on the ground that it is only the lost chance itself, not its value, that needs to be proved on the balance of probabilities: BestCare Foods v Origin Energy [2012] NSWSC 574 (31 May 2012) [49].

5 (1990) 169 CLR 638, 643-4. Brennan and Dawson JJ (at 641) generally agreed, but rejected the idea of using a percentage figure in assessing damages. The facts of the case are set out under heading II: 'Loss Dependent upon a Single Event' below.

${ }^{6}$ The wide scope of application given to the degree-of-probability approach in Malec has been criticised on the ground that 'the calculation of what might/would have been has few signposts to guide the expert who attempts to provide evidence-based opinions. It is a recipe 
context of the extent (as opposed to existence) of liability, as the opening phrase 'When liability has been established' demonstrates. It is thus implied that substantial (as opposed to nominal) damages cannot be awarded unless the plaintiff establishes, on the balance of probabilities, that the defendant's wrong has caused some loss to the plaintiff. In other words, it is implied that even though the degree-of-probability approach applies to hypothetical past events in determining consequential loss, the balance-of-probability approach applies to all types of event (including hypothetical past events) in determining the initial harm.

Subsequently, in Sellars v Adelaide Petroleum $N L{ }^{7}$ the High Court did in effect apply the degree-of-probability approach to hypothetical past events in determining the initial harm. In that case, the defendant's misleading or deceptive conduct ${ }^{8}$ caused the plaintiff to discontinue contractual negotiations with a third party. After discovering the truth, the plaintiff resumed negotiations with the third party, resulting in a contract. It was found that there was a 40 per cent chance that, had the plaintiff not discontinued the initial negotiations with the third party, those negotiations would have led to a contract more favourable to the plaintiff than the contract ultimately executed. ${ }^{9}$ Since it was more likely than not that the defendant's wrong had caused no loss to the plaintiff, no substantial damages could have been awarded had the balance-of-probabilities approach been applied in determining the initial harm. The High Court upheld an award of compensation in the amount of 40 per cent of the sum by which the plaintiff would have been better off under the hypothetical contract with the third party (less some deductions for other adverse contingencies). Mason CJ, Dawson, Toohey and Gaudron JJ stated:

[T]he applicant must prove on the balance of probabilities that he or she has sustained some loss or damage. However, in a case such as the present, the applicant shows some loss or damage was sustained by demonstrating that the contravening conduct caused the loss of a commercial opportunity which had

for a problematic incidence of disagreement and for reasoning that takes into account imponderables and immeasurables': Ian Freckelton, 'Scientific and Medical Evidence in Causation Decisions: The Australian Experience' in Richard Goldberg (ed), Perspectives On Causation (Hart, 2011) 241, 254.

7 (1994) 179 CLR 332.

${ }^{8}$ In violation of what was then the Trade Practices Act 1974 (Cth) s 52, and is today the Competition and Consumer Act 2010 (Cth) sch 2, s 18.

${ }^{9}$ (1994) 179 CLR 332, 347, 358, 365. 
some value (not being a negligible value), the value being ascertained by reference to the degree of probabilities or possibilities. ${ }^{10}$

In that passage, the plurality purported to maintain the Malec distinction between causation (determined on the balance of probabilities) and assessment (undertaken by reference to the degree of probability). However, the presence of 'some loss' can be demonstrated only by using the degree-ofprobability approach, which is thus the starting point of the analysis. In effect, therefore, the plurality applied the degree-of-probability approach in determining the initial harm. The plurality emphasised that the rules announced apply not only under legislation prohibiting misleading or deceptive conduct but also at common law. ${ }^{11}$

The approach taken in Sellars is still applied today where, as in Sellars, the initial harm is pure economic loss. ${ }^{12}$ For some time, it was uncertain whether the approach taken in Sellars applies also where the initial harm is personal injury. ${ }^{13}$ It is now clear that it does not. ${ }^{14}$ The High Court has laid down that in determining whether, but for the defendant's wrong, the plaintiff would have suffered the initial personal injury, uncertainty in relation to hypothetical past conduct by a third party ${ }^{15}$ or a hypothetical past natural event (such as the progress of a medical condition) ${ }^{16}$ is resolved on the balance of probabilities. ${ }^{17}$

10 (1994) 179 CLR 332, 355 (emphasis in original). Brennan J (at 368) employed similar reasoning.

11 (1994) 179 CLR 332, 355.

${ }^{12}$ See, eg, Williams v Pagliuca [2009] NSWCA 250 (19 August 2009) [38], [67]; Donnellan v Woodland [2012] NSWCA 433 (18 December 2012) [235]-[239].

${ }^{13}$ The treatment of property damage is still uncertain.

14 'The law, as it presently stands, allows the peculiar situation that a plaintiff can recover against negligent solicitors for the loss of an opportunity to pursue a personal injury cause of action but not for the loss of an opportunity to avoid the personal injury itself': Richard Leahy and Genovieve Lajeunesse, 'Loss of Opportunity Claims against Professionals: A Physical Injury by Any Other Name Would Sound in Damage' (2009) 20 Insurance Law Journal 197, 207.

${ }^{15}$ Adeels Palace Pty Ltd v Moubarak (2009) 239 CLR 420 (no liability in negligence for the loss of a less than even chance that a particular third party would not have shot at the plaintiff). For English law on this issue, see Wright v Cambridge Medical Group [2011] EWCA Civ 669, [2013] QB 312 [84] (Lord Neuberger).

${ }^{16}$ Tabet v Gett [2010] HCA 12, (2010) 240 CLR 537 (no liability in negligence for the loss of a 40 per cent chance of avoiding the deterioration of a medical condition), disapproving Rufo $v$ Hosking (2004) 61 NSWLR 678, and following Laferrière v Lawson [1991] 1 SCR 541 and Gregg v Scott [2005] UKHL 2, [2005] 2 AC 176. A patient who loses a 51 per cent chance of a better medical outcome thus recovers in full: Naxakis $v$ Western General Hospital (1999) 197 CLR 269 [28]-[36] (Gaudron J).

${ }^{17}$ The balance-of-probability approach may also apply to the initial harm where that harm is imprisonment: Lewis v Hillhouse [2005] QCA 316 (26 August 2005) [22]-[27] (no substantial 
This rule does not affect what was said in Malec, namely that consequential loss dependent upon hypothetical past events is assessed by reference to the degree of probability that, but for the event, the loss would not have occurred. This rule continues to apply even where the initial harm is personal injury. ${ }^{18}$ In personal injury cases, therefore, hypothetical past natural events and hypothetical past actions of third parties are governed by the balance-ofprobabilities approach in determining whether the plaintiff would have suffered the initial injury but for the defendant's wrong, and are governed by the degree-of-probabilities approach in determining what would have happened to the plaintiff had she not suffered the initial injury. ${ }^{19}$

There is one additional complexity, which is the subject matter of this article. In the passage from Malec quoted above, the High Court made the sweeping statement that (among other things) hypothetical past events, and thus all hypothetical past events, are assessed by reference to the degree of probability once liability has been established. Under heading II it will be demonstrated that this statement remains true of natural events (including animal behaviour) and conduct by third parties, but is no longer true (if it ever was) of conduct by the plaintiff, which is always assessed on the balance of probabilities. Different types of hypothetical past event are thus subjected to different ways of resolving uncertainty. This raises two questions, which this article explores. First, what is the rationale for the difference? Secondly, how is uncertainty to be resolved where a single head of loss depends upon two or more uncertain events, in particular where those events, considered separately, would not all be governed by the same approach to resolving uncertainty? This article considers loss dependent upon a single event (heading II), loss dependent upon multiple events of the same type (heading III) and loss dependent upon multiple events of different types (heading IV). It is assumed throughout that the loss in question is either pure economic loss or loss consequent upon harm already established on the balance of probabilities.

Finally, it is necessary to explain particular terminology used in this article, namely the distinction between an event that is 'identifiable' and an event that constitutes an 'unidentifiable' part of a mix of multiple events. An identifiable event is an event that can be described with some degree of specificity in terms of its form, time and, where relevant, location. An example is the signing of a particular document by a particular person at a particular time. An unidentifiable part of a mix of multiple events can be described only in a

\footnotetext{
damages for loss of a less than even chance of avoiding being convicted of crimes and sentenced to imprisonment).

${ }^{18}$ See, eg, Phillips v MCG Group Pty Ltd [2013] QCA 83 (16 April 2013) [60]-[65], [74]-[75].

${ }^{19}$ See, eg, Ridolfi v Hammond [2012] NSWCA 3 (6 February 2012) [84]-[88].
} 
general manner. An example is hypothetical conduct by a litigant or contract negotiator. It is clear that such a person would have taken some actions during the hypothetical litigation or negotiations. But it often cannot be said with any specificity what actions the person would have taken and when. The demarcation line between identifiable and unidentifiable events is no doubt blurred, but this article will show that the distinction in principle is important.

\section{Loss Dependent upon A Single Event}

Sometimes, the assessment of a plaintiff's loss requires the resolution of uncertainty with regard to only one hypothetical past event. It may be that this event is the only relevant event, or it may be that the hypothetical occurrence or non-occurrence of all other relevant events is certain or virtually certain. Which of the two basic approaches of resolving an uncertainty (balance of probabilities or degree of probability) applies in those circumstances depends upon the type of event. It is necessary to distinguish between natural events, conduct by a third party, conduct by the plaintiff and conduct by the defendant.

Natural events are all events other than conscious human conduct, for example the progress of a medical condition. The applicability of the degreeof-probability approach to hypothetical past natural events was laid down in Malec v J C Hutton Pty Ltd. ${ }^{20}$ The defendant employer's negligence caused the plaintiff employee to contract brucellosis and to develop a neurotic illness, rendering him unable to work. Soon afterwards, the plaintiff developed a back condition, which alone would have rendered him unemployable. It was probable, but not certain, that, even if he had not contracted brucellosis, the plaintiff would have developed the back condition and that condition, coupled with the resulting unemployment, would have caused the plaintiff to develop a neurotic illness. The Full Court of the Supreme Court of Queensland assessed the matter on the balance of probabilities and denied damages for the time after the onset of the back condition. The High Court of Australia overturned that judgment on the ground that the plaintiff's loss was to be assessed, not on the balance of probabilities, but by reference to the degree of probability of the relevant events occurring. ${ }^{21}$ The decision is still good authority for the

\footnotetext{
${ }^{20}$ (1990) 169 CLR 638. Another instructive case is Karam v Palmone Shoes Pty Ltd [2010] VSCA 253 (29 September 2010) [85]-[87].

${ }^{21}$ The key passage in the judgment by Deane, Gaudron and McHugh JJ is quoted in the Introduction of this article.
} 
proposition that loss dependent upon a hypothetical past natural event is assessed by reference to the degree of probability of the event occurring. ${ }^{22}$

The same approach applies to hypothetical past conduct by third parties. ${ }^{23}$ An example is Hendriks $v$ McGeoch, ${ }^{24}$ where a solicitor was instructed to draw up a will but negligently failed to do so before the testatrix died. The beneficiary under the intended will sought to recover from the solicitor the value of what he would have received had that will been made. It was likely, but not certain, that the testatrix would have executed the will had it been drawn up. The trial judge regarded this as a sufficient basis to award damages in the full amount of the lost inheritance. ${ }^{25}$ The New South Wales Court of Appeal reduced the award to 80 per cent of the lost inheritance, finding a 20 per cent chance that the testatrix would not have executed the will even if it had been drawn up. ${ }^{26}$

By contrast, hypothetical past conduct by the plaintiff is assessed on the balance of probabilities. ${ }^{27}$ An example is Crown Insurance Services Pty Ltd $v$ National Mutual Life Association of Australasia Ltd, ${ }^{28}$ where an insurer issued a policy of disability insurance to a person who, unknown to the insurer, had had a CT scan and X-ray of his spine. The insurer's agent had obtained the insured's signature on a blank proposal form and failed to ask about the insured's medical conditions. The insured claimed the insurance benefits, alleging that he had become disabled two weeks after the policy was issued. The insurer settled the claim with the insured and claimed reimbursement from the agent, who was liable to the insurer in contract and tort for failing to ask the insured about his medical conditions.

\footnotetext{
${ }^{22}$ See, eg, Wilson v Collingwood Store Pty Ltd [2014] VSCA 20 (25 February 2014) [33]-[40].

${ }^{23}$ Employees of either party are not third parties for present purposes; see Bank of Credit and Commerce International SA v Ali (No 2) [2002] EWCA Civ 82 [72] (Robert Walker LJ).

${ }^{24}$ [2008] NSWCA 53. Another example is Heenan v Di Sisto [2008] NSWCA 25.

${ }^{25}$ McGeoch v Hendriks (No 2) [2007] NSWSC 364 (13 April 2007) [3].

${ }^{26}$ [2008] NSWCA 53 [19], [87]-[99].

${ }^{27}$ Hanflex Pty Ltd $v$ NS Hope \& Associates [1990] 2 Qd R 218, 228; Hall v Foong (1995) 65 SASR 281, 301; Heenan $v$ Di Sisto [2008] NSWCA 25 [32]; Fabcot Pty Ltd v Port Macquarie-Hastings Council [2010] NSWSC 726 (2 July 2010) [140]; Doolan v Renkon Pty Ltd (2011) 21 Tas R 156 [60]; Falkingham v Hoffmans (a firm) [2014] WASCA 140 (1 August 2014) [40]. Cf Bak v Glenleigh Homes Pty Ltd [2006] NSWCA 10 (15 February 2006) [73]-[74]; Berryman v Hames Sharley (WA) Pty Ltd (2008) 38 WAR 1 [802]. It is asked what the individual plaintiff, not a reasonable person in the plaintiff's position, would have done in the absence of the defendant's wrong: Dickinson v National Mutual Life Association of Australasia Ltd [2003] VSC 325 [23]; Falkingham v Hoffmans (a firm) [2014] WASCA 140 (1 August 2014) [41].

${ }^{28}$ [2005] VSCA 218.
} 
It was found, as a certainty, that the insured would have revealed the CT scan and X-ray had the medical questions on the proposal form been put to him. ${ }^{29}$ It was further found that there was an 80 per cent probability that the insurer, if advised of the CT scan and X-ray, would still have issued an insurance policy without excluding liability for back injury. ${ }^{30}$ The trial judge held that the insurer was entitled to damages in the amount of 20 per cent of the settlement sum. The Victorian Court of Appeal substituted an award of nominal damages on the ground that the insurer had not established, on the balance of probabilities, that, but for the agent's wrong, it would have excluded liability for back injury. ${ }^{31}$

The way in which uncertainty in relation to a hypothetical past event is to be resolved thus depends upon the type of event. Conduct by the plaintiff is assessed on the balance of probabilities whereas conduct by third parties and natural events are assessed by reference to the degree of probability. To illustrate this with an example, suppose that the defendant has wrongfully deprived the plaintiff, who owns a race horse, of possession of the horse for some time. Uncertainty as to whether, but for the defendant's wrong, the plaintiff would have decided to enter the horse in a particular race during the period of dispossession will be resolved on the balance of probabilities. But uncertainty as to what the horse and the jockey (a third party) would have done in a particular race had they participated is resolved by reference to the degree of probability.

The different treatment of conduct by the plaintiff and conduct by third parties is particularly striking. With regard to the same distinction in English law, ${ }^{32}$ Lord Hoffmann stated in Gregg v Scott: 'This apparently arbitrary distinction obviously rests on grounds of policy'. ${ }^{33}$ Unfortunately, he did not specify what those policy grounds are. A purely pragmatic rationale of the distinction was suggested by Mance LJ in the same case, who stated that the rationale must be

the pragmatic consideration that a claimant may be expected to adduce persuasive evidence about his own conduct (even though hypothetical), whereas

\footnotetext{
${ }^{29}$ The insured gave evidence to that effect, which was accepted by the trial judge: Dickinson $v$ National Mutual Life Association of Australasia Ltd [2003] VSC 325 [22].

${ }^{30}$ Dickinson v National Mutual Life Association of Australasia Ltd [2003] VSC 325 [41]-[43].

31 [2005] VSCA 218 [14].

${ }^{32}$ Allied Maples Group Ltd $v$ Simmons \& Simmons [1995] 1 WLR 1602, 1610-11.

${ }^{33}$ Gregg v Scott [2005] 2 AC 176 [83].
} 
proof of a third party's hypothetical conduct may often be more difficult to adduce. ${ }^{34}$

This rationale is weak because, to use Mance LJ's words, 'persuasive evidence' about what third parties would have done may be before the court where they have appeared as witnesses, ${ }^{35}$ and evidence about what the plaintiff would have done may be 'difficult to adduce'. A key piece of evidence on what the plaintiff would have done will often be the plaintiff's own testimony. But this is not always available. The plaintiff may be unable to give evidence because of mental incapacity or youth. Moreover, the civil liability statutes of four Australian jurisdictions provide that evidence by an injured person about what he or she would have done but for the defendant's wrong is inadmissible, at least where such evidence would favour the injured person. ${ }^{36}$

Since the plaintiff cannot be expected to adduce persuasive evidence about the defendant's conduct, loss dependent upon what the defendant would have done should be assessed by reference to the degree of probability. ${ }^{37}$ While this approach has been endorsed in some cases, ${ }^{38}$ an assessment on the balance of probabilities has been made in others. ${ }^{39}$ The law is unclear in this respect. ${ }^{40} \mathrm{In}$ the remainder of this article, hypothetical past conduct by the defendant will be considered only insofar as it is part of a mix of unidentifiable events.

${ }^{34}$ Gregg v Scott [2002] EWCA Civ 1471, (2003) 71 BMLR 16 [71]. The same view is taken by Andrew Burrows, 'Uncertainty about Uncertainty: Damages for Loss of a Chance' [2008] Journal of Personal Injury Law 31, 36-7. See also Harvey McGregor, McGregor on Damages (Sweet \& Maxwell, 19 ${ }^{\text {th }}$ ed, 2014) [10-060]; Sandy Steel, 'Rationalising Loss of a Chance in Tort' in Stephen G A Pitel, Jason W Neyers and Erika Chamberlain (eds), Tort Law: Challenging Orthodoxy (Hart, 2013) 235, 249.

35 The degree-of-probability approach applies to third parties' hypothetical conduct even where they have given evidence: Tom Hoskins plc v EMW (a firm) [2010] EWHC 479 (Ch) [126].

${ }^{36}$ Civil Liability Act 2002 (NSW) s 5D(3)(b); Civil Liability Act 2003 (Qld) s 11(3)(b); Civil Liability Act 2002 (Tas) s 13(3)(b); Civil Liability Act 2002 (WA) s 5C(3)(b). For the types of wrong to which each of those statutes applies, see Barnett and Harder, above n 1, 56-7.

37 The balance-of-probabilities approach should apply if, exceptionally, the defendant bears the legal onus of proof in relation to what he would have done but for his wrong: Harvey McGregor, McGregor on Damages (Sweet \& Maxwell, 19 ${ }^{\text {th }}$ ed, 2014) [10-061].

${ }^{38}$ See, eg, Fink v Fink (1946) 74 CLR 127, 135; Sellars v Adelaide Petroleum NL (1994) 179 CLR 332, 349; McCrohon v Harith [2010] NSWCA 67 [97]; Silverbrook Research Pty Ltd v Lindley [2010] NSWCA 357 (17 December 2010) [2].

${ }^{39}$ See, eg, Australian Winch and Haulage Co Pty Ltd $v$ Collins [2013] NSWCA 327 (9 October 2013) [17], [112]-[122]. See also Commonwealth v Amann Aviation Pty Ltd (1991) 174 CLR 64, where a majority in the High Court of Australia held that reliance damages in relation to the repudiation of a long-term contract should not be discounted to reflect the possibility of lawful termination of the contract by the repudiating party.

${ }^{40}$ Barnett and Harder, above n 1, 38-9. 


\section{Loss Dependent upon Multiple Events OF THE SAME TYPE}

Sometimes, the assessment of a plaintiff's loss requires the resolution of uncertainty with regard to two or more hypothetical past events and all those events are governed by the same approach to resolving uncertainty. Since there are two approaches, two categories of case must be distinguished.

First, all events may be of a type in relation to which uncertainty is resolved on the balance of probabilities. This is the case where the plaintiff's loss depends upon two or more hypothetical past actions by herself (and no other uncertain hypothetical events). It ought to be uncontroversial that uncertainty in those circumstances will always be resolved on the balance of probabilities, and that there is no room for a resolution by reference to the degree of probability. It is all or nothing. This approach is straightforward where the actions are inextricably interwoven. In that case, the balance-of-probabilities test can only be applied to the mix of actions as a whole. Assuming that the plaintiff's actions would have been to her advantage, the plaintiff will receive full compensation if it is more likely than not that, but for the defendant's wrong, the whole mix of actions would have occurred, and the plaintiff will receive nothing otherwise.

Where the plaintiff's hypothetical actions are identifiable, the balance-ofprobabilities test may be applied to each action separately or to the group of actions as a whole. Where the actions would have formed a chain of events, each action being available only after the previous one had been taken, the two methods produce the same outcome in two cases. (1) If the probability of any one action occurring is less than 50 per cent, the plaintiff's claim will fail; (2) if the probability of the whole group of actions occurring is more than 50 per cent, the plaintiff will receive full compensation. ${ }^{41}$ The two methods will come to different outcomes if the individual probability of each action in the chain occurring is more than 50 per cent but the overall probability of the whole group of actions occurring is less than 50 per cent.

Consider the following example. The defendant wrongfully failed to offer the plaintiff a contract that would have provided the plaintiff with an option to acquire a particular asset at a later date. There is a 60 per cent chance that the plaintiff would have accepted an offer by the defendant to enter into that contract, and a 60 per cent chance that the plaintiff, had she entered into the contract, would have exercised the option and acquired the asset. Thus, it is more likely than not that the plaintiff would have entered into the contract but

\footnotetext{
${ }^{41}$ It is, again, assumed that the plaintiff's actions would have been to her advantage.
} 
for the defendant's wrong, and it is more likely than not that the plaintiff would have exercised the option had she entered into the contract. But the overall probability of the plaintiff exercising the option but for the defendant's wrong is only 36 per cent ( 60 per cent of 60 per cent). In those circumstances, the courts are likely to apply the balance-of-probabilities approach to each hypothetical action by the plaintiff separately, and award full compensation.

The second category of case to be discussed under this heading is where all events upon which the plaintiff's loss depends are of a type in relation to which uncertainty is resolved by reference to the degree of probability. All events may be natural events or hypothetical actions by third parties or a mix of both. In those circumstances, the plaintiff's loss is assessed by reference to the degree of probability of the events occurring, provided that the court has sufficient material to make at least a rough estimate of that degree. Where the events are inextricably interwoven, the court will determine the degree of probability of the whole mix of events occurring. For example, where the loss suffered by the plaintiff as a result of the defendant's wrong depends upon whether an action by $\mathrm{X}$ against $\mathrm{Y}$ (which was not brought but would have been brought but for the defendant's wrong) would have been successful, the court will determine the degree of probability of the whole action succeeding, as opposed to the degree of probability of either litigant performing a particular act during the proceedings.

Where there are multiple identifiable events, the court may determine the degree of probability for each event separately (and then multiply the figures) or for the whole group of events together. A direct estimation of the overall probability for the whole group of events may yield a figure that differs slightly from the result of multiplying individual figures for each event. But since all these figures are often rough estimates to start with, it cannot be said that one approach is more precise than the other. ${ }^{42}$ Crucially, the outcome will always be an award of compensation for part of the loss, and the court is not forced to choose between all and nothing. This is an important way in which this category differs from the first category discussed under this heading.

\section{LOSS DEPENDENT UPON MULTIPLE EVENTS OF DIFFERENT TYPES}

Sometimes, the assessment of a plaintiff's loss requires the resolution of uncertainty with regard to two or more hypothetical past events and those

\footnotetext{
${ }^{42}$ See, in a different context, Nigam v Harm (No 2) [2011] WASCA 221 (18 October 2011) [154]-[155], [260], [266].
} 
events are not all governed by the same approach to resolving uncertainty. In other words, loss sometimes depends upon hypothetical past conduct by the plaintiff and also upon hypothetical past conduct by a third party or a hypothetical past natural event or both. In those circumstances, the overall approach depends upon whether or not events of different types are inextricably interwoven.

Things are relatively straightforward where each hypothetical past event is identifiable. In that case, each event is governed by the approach that applies to that type of event, as discussed under heading II. Thus, the balance-ofprobabilities approach applies to conduct by the plaintiff, and the degree-ofprobability approach applies to natural events and to conduct by third parties. For example, where a bank provides a loan to a borrower in reliance on a valuer's negligent overvaluation of the loan security, and the bank argues that, but for the valuer's negligent advice, it would have loaned the same amount of money to another customer and made a profit, the bank must first prove, on the balance of probabilities, that it would have attempted to loan the money to another customer, and the bank's loss will then be assessed by reference to the degree of probability of the other customer taking out the loan and repaying it. $^{43}$

Another example is Heenan $v$ Di Sisto. ${ }^{44}$ The complex facts of that case may be distilled into the following brief outline. The owners of two adjoining properties entered into simultaneous but separate contracts for the sale of those properties to the same developer. Neither contract made its completion dependent upon the completion of the other. The developer failed to complete either contract and subsequently went into liquidation. The vendors sold the properties for a lower price on the market, and sought to recover the difference from the solicitor who had acted for them in the negotiations with the developer. It was found that the solicitor had been negligent in failing to ask the vendors whether the two contracts should be made interdependent.

If the solicitor had raised that question, three events would have been necessary to avoid the loss actually suffered: first, the vendors would have had to give an affirmative answer to the question; second, the developer would have had to enter into contracts with an interdependency clause; thirdly, the developer would have had to complete those contracts. The trial judge found that it was more likely than not (albeit not certain) that all three

\footnotetext{
${ }^{43}$ La Trobe Capital \& Mortgage Corp Ltd v Hay Property Consultants Pty Ltd (2011) 190 FCR 299 [89]-[90]; Angas Securities Ltd v Valcorp Australia Pty Ltd (2011) 277 ALR 538 [214].

44 [2008] NSWCA 25. See also Tasmanian Sandstone Quarries Pty Ltd v Tasmanian Sandstone Pty Ltd [2009] SASC 111 (24 April 2009) [286]-[287], [391]-[395].
} 
events would have occurred but for the solicitor's negligence. ${ }^{45}$ Applying the balance-of-probabilities approach to the group of events as a whole, the trial judge awarded full compensation. ${ }^{46}$

The New South Wales Court of Appeal overturned the judgment on the ground that, while the vendors' hypothetical decision was to be determined on the balance of probabilities, the developer's hypothetical decisions were to be approached separately according to the degree of probability. ${ }^{47}$ The court found that there was an 80 per cent chance that the developer would have entered into contracts with an interdependency clause, and a 70 per cent chance that the developer would have completed such contracts. ${ }^{48}$ There was thus a 56 per cent chance that the developer would have completed contracts with an interdependency clause. Rounding it up, the court awarded compensation in the amount of 60 per cent of the vendors' loss. ${ }^{49}$

Things are also relatively straightforward where the plaintiff's loss depends upon a mix of unidentifiable events of the same type as well as one identifiable event of the other type. In that case, the rules discussed under heading II apply to the identifiable event, and the rules discussed under heading III apply to the mix of unidentifiable events.

For example, suppose that many grapes on the plaintiff's vineyard have been eaten by birds since the defendant wrongfully deprived the plaintiff of an opportunity to develop and test a new method of repelling birds. The plaintiff's loss depends upon two factors. One is whether, but for the defendant's wrong, the plaintiff would have installed a particular method of repelling birds. This is a mix of unidentifiable hypothetical past actions by the plaintiff, governed by the balance-of-probabilities approach. The other factor upon which the plaintiff's loss depends is whether the method in question, if installed, would have kept the birds away. This is a hypothetical past natural event (in the form of animal conduct), governed by the degree-of-probability approach. Thus, the plaintiff must first prove, on the balance of probabilities, that she would have used a particular method of repelling birds but for the defendant's wrong. If this is successful, the plaintiff's loss will then be assessed by reference to the degree of probability that the method would have kept the birds away.

\footnotetext{
${ }^{45}$ Di Sisto v Skyworld Pty Ltd [2006] NSWSC 1182, [28], [40].

${ }^{46}$ Ibid [41]. The same approach was taken in Gore (t/a Clayton Utz) v Montague Mining Pty Ltd [2000] FCA 1214, [70].

47 [2008] NSWCA 25, [28]-[34].

${ }^{48}$ Ibid [47]-[49].

${ }^{49}$ Ibid [50].
} 
Things are less clear where the plaintiff's loss depends wholly or partly on a mix of unidentifiable events of different types. Since the events are unidentifiable, one approach must apply to the mix of events as a whole, even though some of the events in the mix would be governed by the other approach if they were identifiable. For example, where the defendant has wrongfully deprived the plaintiff of an opportunity to bring an action against a third party, the plaintiff's loss depends upon the outcome of the hypothetical litigation, which in turn depends upon what the plaintiff and the third party would have done during the proceedings. If the parties' actions are identifiable, the balance-of-probabilities approach will apply to the plaintiff's actions, and the degree-of-probability approach will apply to the third party's actions. But the parties' actions in hypothetical court proceedings are usually unidentifiable. It is therefore necessary to apply one of the two approaches to the hypothetical litigation as a whole.

In some cases involving a heterogeneous mix of unidentifiable events, a choice between the two approaches is unnecessary. Where the plaintiff's loss depends partly upon a mix of unidentifiable events of different types, the loss often depends also on an identifiable action by the plaintiff. In cases of nondisclosure or wrong advice, for example, the initial question is usually how the plaintiff would have reacted to disclosure or correct advice. It is established that this preliminary question is determined on the balance of probabilities. ${ }^{50}$ If it cannot be proved that disclosure or correct advice would have made a difference, the plaintiff's claim will fail at the first hurdle and the mix of subsequent hypothetical events will no longer be relevant.

A plaintiff may succeed in proving that she would have taken a particular action but for the defendant's wrong, or a plaintiff's loss may wholly depend upon a mix of unidentifiable events of different types. In those circumstances, a choice between the two competing approaches must be made. On principle, the degree-of-probability approach ought to apply. It is the approach that generally applies to hypothetical past events. The applicability of the balanceof-probability approach to hypothetical past conduct by the plaintiff is an exception to the rule, defended with the argument that the plaintiff can be expected to adduce persuasive evidence about what she would have done but for the defendant's wrong. ${ }^{51}$ The same cannot be said of a mix of

\footnotetext{
${ }^{50}$ See, eg, Hall v Foong (1995) 65 SASR 281, 301; Tasmanian Sandstone Quarries Pty Ltd v Tasmanian Sandstone Pty Ltd [2009] SASC 111 (24 April 2009) [286]-[287]; Firth v Sutton [2010] NSWCA 90 (30 April 2010) [103].

${ }^{51}$ Gregg v Scott [2002] EWCA Civ 1471 [71] (Mance LJ), discussed under heading II of this article.
} 
unidentifiable events that contains hypothetical past events other than conduct by the plaintiff.

Indeed, the applicability of the degree-of-probability approach is or should be established for three important types of heterogeneous mix of unidentifiable events. The first mix of events is formed by hypothetical contractual negotiations between the plaintiff and a third party, to which the High Court of Australia applied the degree-of-probability approach in Sellars $v$ Adelaide Petroleum $N L,{ }^{52}$ mentioned above. ${ }^{53}$ The second mix of events is hypothetical litigation between the plaintiff and a third party. Once the plaintiff has proved, on the balance of probabilities, ${ }^{54}$ that she would have issued and pursued proceedings against a third party but for the defendant's wrong, the plaintiff's loss is assessed by first determining the likely amount that would have been awarded had the plaintiff won the action, and by then discounting this amount by the degree of probability that the action might have been unsuccessful. ${ }^{55}$ However, the plaintiff receives nothing unless there is an evidentiary foundation for concluding that the plaintiff would have had some prospect of winning the action. ${ }^{56}$

The third mix of events is the plaintiff's hypothetical past employment, ${ }^{57}$ which is particularly relevant to the assessment of past loss of earning capacity caused by personal injury. The resolution of uncertainty by reference to the degree of probability in those circumstances is illustrated by Bell $v$

\footnotetext{
52 (1994) 179 CLR 332.

53 The degree-of-probability approach was also taken in, eg, Glenmont Investments Pty Ltd $v$ O'Loughlin (2000) 79 SASR 185 [429]; University of Western Australia v Gray (No 28) (2010) 185 FCR 335 [59]-[60]. By contrast, the balance-of-probability approach was taken in, eg, St George Bank Ltd v Quinerts Pty Ltd (2009) 25 VR 666 [22]; King v Benecke [2013] NSWSC 568 (23 August 2013) [665]. An artificial identification of actions by the plaintiff and actions by the third party was undertaken in Dayman v Lawrence Graham [2008] EWHC 2036 (Ch) [81].

${ }^{54}$ Falkingham v Hoffmans (a firm) [2014] WASCA 140 (1 August 2014) [40], [216], [219].

${ }^{55}$ See, eg, Leitch v Reynolds [2005] NSWCA 259 [85]-[86]; Worthington v Da Silva [2006] WASCA 180 (7 September 2006) [125]-[130]; Firth v Sutton [2010] NSWCA 90 (30 April 2010) [160]; Nigam v Harm (No 2) [2011] WASCA 221 (18 October 2011) [258]-[266]; Falkingham v Hoffmans (a firm) [2014] WASCA 140 (1 August 2014) [44], [237]; Molinara $v$ Perre Bros Lock 4 Pty Ltd [2014] SASCFC 115 (30 October 2014) [80]. Cf Johnson v Perez (1988) 166 CLR 351, 372 (Brennan J); Molinara v Perre Bros Lock 4 Pty Ltd [2014] SASCFC 115 (30 October 2014) [48] (Kourakis CJ).

${ }^{56}$ Witcombe (as executrix of the estate of Witcombe v Talbot \& Olivier (2011) 280 ALR 177 [118]; Moss v Eagleston [2014] NSWSC 6 (4 March 2014) [151]-[152].

${ }^{57}$ See, eg, Johnson v Forefront Automotives Industries [2013] ACTSC 44 (20 March 2013) [101]-[103]; Phillips v MCG Group Pty Ltd [2013] QCA 83 (16 April 2013) [56]; MacDonald v Mailander [2014] ACTSC 45 (14 March 2014) [65]-[66].
} 
Mastermyne Pty $L t d,{ }^{58}$ where the plaintiff, who had had a poor working history, suffered a serious back injury shortly after he commenced working for the defendant's mining business. It was found that, even if he had not been injured, his prospect of maintaining employment in the mining industry was only 10 per cent. ${ }^{59}$ Assessing the plaintiff's loss of earning capacity in the period between the accident and the trial, the trial judge took ten per cent of the amount that the plaintiff would probably have earned in the mining industry in that period, ${ }^{60}$ and added to this 90 per cent of the amount that the plaintiff would probably have earned in another job in that period. ${ }^{61}$ From this sum, the judge made a discount to reflect the possibility that a pre-existing spinal condition would have diminished the plaintiff's earning capacity during the relevant period in any event. ${ }^{62}$

When a court assessing loss is required to determine what the plaintiff would have done but for the defendant's wrong, the approach taken to resolve uncertainty thus depends upon whether the plaintiff's hypothetical past conduct is identifiable, or is an unidentifiable part of a heterogeneous mix of events. In the former case, the balance-of-probabilities approach applies. In the latter case, at least in particular circumstances, the degree-of-probability approach applies to the whole mix of events including the plaintiff's conduct. It is therefore important to have clear and justifiable criteria for determining, in a borderline case, whether particular conduct by the plaintiff is identifiable. Those criteria ought to be informed by the rationale for applying the balanceof-probabilities approach to identifiable hypothetical conduct by the plaintiff. It has been suggested that the rationale lies in the expectation that the plaintiff be able to adduce persuasive evidence about what she would have done but for the defendant's wrong. ${ }^{63}$ On the basis of that argument, the classification of hypothetical past conduct by the plaintiff as identifiable or unidentifiable ought to depend upon whether the plaintiff can in principle be expected to adduce persuasive evidence about that conduct.

\footnotetext{
${ }^{58}$ [2008] QSC 331 (18 December 2008).

${ }^{59}$ Ibid [67].

${ }^{60}$ Ibid [97].

${ }^{61}$ Ibid [98].

${ }^{62}$ Ibid [99]. The judge made a discount of 35 per cent to reflect both the pre-existing spinal condition and the residual earning capacity left after the workplace injury.

${ }^{63}$ Gregg v Scott [2002] EWCA Civ 1471 [71] (Mance LJ), discussed under heading II of this article.
} 


\section{CONCLUSION}

The quantification of loss suffered by the victim of a civil wrong depends upon what would have happened but for the wrong. Where this cannot be established with certainty, the law must choose between two fundamentally different approaches of assessing the plaintiff's loss. On the one hand, the loss may be assessed on the balance of probabilities, resulting in either an award of full compensation or a complete denial of compensation, depending upon which hypothesis is more likely to be true. On the other hand, the plaintiff's loss may be assessed by reference to the degree of probability that an event would have occurred but for the defendant's wrong, resulting in partial recovery by the plaintiff.

Where a hypothetical past event can be identified with a sufficient degree of specificity, Australian courts apply the degree-of-probability approach to conduct by third parties and natural events (at least if liability has already been established), but apply the balance-of-probabilities approach to conduct by the plaintiff. Australian courts have given no reason for this difference in approach. It has been suggested that the rationale lies in the expectation that the plaintiff be able to adduce persuasive evidence about what she would have done but for the defendant's wrong.

The application of different methods of resolving uncertainty to different types of hypothetical past event is generally unproblematic where the plaintiff's loss depends only upon a single event, or events of the same type, or a heterogeneous group of identifiable events. Practical problems arise where unidentifiable events of different types are inextricably interwoven, and one of the two approaches must be applied to the mix of events as a whole. In those circumstances, the degree-of-probability approach ought to apply as a matter of principle, and has in fact been applied to the plaintiff's hypothetical past employment and to hypothetical past litigation or contractual negotiations between the plaintiff and a third party.

Hypothetical past conduct by the plaintiff will thus be governed by the degree-of-probability approach if the conduct is an unidentifiable part of a mix of heterogeneous events, and will be governed by the balance-ofprobabilities approach otherwise. Where it is doubtful whether the plaintiff's hypothetical past conduct ought to be classified as identifiable or unidentifiable, the classification ought to depend upon whether the plaintiff can in principle be expected to adduce persuasive evidence about that conduct. 